\title{
Summary of Toxicology Studies with Alachlor
}

\author{
William F. HEYDENS \\ Toxicology Division, Monsanto Company
}

(Received July 8, 1998 ; Accepted November 20, 1998)

\section{DESCRIPTION OF THE TEST CHEMICAL}

Alachlor was developed by Monsanto Company (USA) and introduced in 1967 for pre-emergence or pre-plant control of a broad spectrum of grass, sedge, and broadleaf weeds in corn, soybeans, dry beans, cotton, grain sorghum, sunflowers, peanuts, and other crops. In Japan, alachlor was first introduced in 1970 and has been used for the control of annual grass weeds in upland crops including corn, soybean, peanut, kidney bean, vegetables and strawberry.

Alachlor is a member of the chloroacetanilide class of chemistry and is the herbicidal active ingredient in LASSO $^{\circledR}$ EC herbicide. This report summarizes the results of laboratory toxicology studies conducted with alachlor. The physical and chemical properties of alachlor are given below:

Common name: Alachlor

Chemical name: 2-chloro-2',6'-diethyl- $N$-(methoxymethyl)acetanilide

Chemical structure:

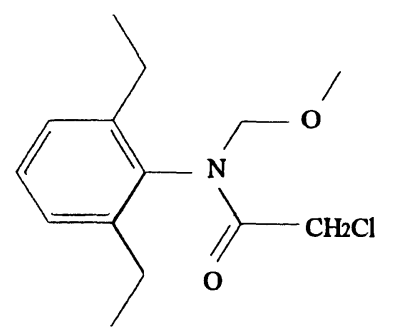

Molecular formula: $\mathrm{C}_{14} \mathrm{H}_{20} \mathrm{ClNO}_{2}$

Molecular weight: 269.8

Physical state: solid at room temperature

Melting point: approximately $38^{\circ} \mathrm{C}$

Vapor pressure: $1.6 \times 10^{-5} \mathrm{mmHg}$ at $25^{\circ} \mathrm{C}$

Decomposition temperature: $105^{\circ} \mathrm{C}$

Water solubility: $242 \mathrm{ppm}$ at $25^{\circ} \mathrm{C}$

\section{ACUTE TOXICITY STUDIES}

\section{Alachlor Technical Material}

The results of acute toxicity studies with alachlor are displayed in Table 1. In these tests, no distinctive signs of toxicity were observed following exposure via the different routes.

\section{Lasso $^{\circledR}$ EC Herbicide}

The results of acute toxicity studies with the formulated product, Lasso ${ }^{\circledR}$ EC Herbicide, are shown in Table 2. Lasso $\mathrm{EC}^{\circledR}$ is an organic solvent-based liquid formulation containing approximately $43 \%$ alachlor.

\section{IRRITATION STUDIES}

\section{Primary Dermal Irritation}

Alachlor was topically applied to the shaved backs of 6 New Zealand white rabbits (2 sites per rabbit). Continuous $24 \mathrm{hr}$ exposure resulted in very slight to slight erythema and edema. The primary irritation index was calculated to be 1.9 on a scale of 8.0. Alachlor was slightly irritating to the rabbit skin.

(Bio/dynamics Inc., 1979)

\section{Primary Ocular Irritation}

Alachlor was placed into the conjunctival sac of the right eye of 6 New Zealand white rabbits. The collateral eye served as the control. Treated eyes were rinsed $24 \mathrm{hr}$ after application. There were no signs of significant irritation in any of the rabbits tested (irritation index of 0.4 on a scale of 110). The eyes of 3 rabbits had no signs of irritation on the day following treatment, and the eyes of the remaining 3 rabbits were clear of irritation by day 3. Alachlor was nonirritating to the eyes of rabbits.

(Bio/dynamics Inc., 1979)

\section{DERMAL SENSITIZATION STUDIES}

The potential of alachlor to induce delayed dermal hypersensitivity was evaluated in a modified Buehler assay. ${ }^{1,2)}$ Induction involved topical exposure of 5 male and 5 female Hartley albino guinea pigs to undiluted alachlor for $6 \mathrm{hr}, 3$ days per week for three weeks. Treated and naive guinea pigs ( 3 per sex) were challenged with undiluted alachlor 2 weeks after the last induction dose. Alachlor produced essentially no irritation following initial application; erythema, edema and/or necrosis were observed in some animals during subsequent repeated exposures in the induction phase. On challenge, 8 out of 10 animals exhibited a positive skin response. Alachlor is considered to be a dermal sensit- 
Table 1 Results of acute toxicity tests with alachlor.

\begin{tabular}{llr}
\hline $\begin{array}{l}\text { Route of } \\
\text { administration }\end{array}$ & Species & Median lethal dose \\
\hline Oral & Rat $^{\text {a) }}$ & $1350 \mathrm{mg} / \mathrm{kg}$ \\
& Mouse $^{\text {b) }}$ & $1100 \mathrm{mg} / \mathrm{kg}$ \\
& Rabbit $^{\mathrm{c})}$ & $1740 \mathrm{mg} / \mathrm{kg}$ \\
Dermal & Rabbit $^{\mathrm{d})}$ & $13300 \mathrm{mg} / \mathrm{kg}$ \\
Inhalation & Rat $^{\mathrm{e}}$ & $>5.1 \mathrm{mg} / l^{\mathrm{f}}$ \\
\hline
\end{tabular}

a) Bio/dynamics Inc., 1985. b) Tokyo Dental College, 1969. c) Younger Laboratories, 1969. d) Bio/ dynamics Inc., 1979. e) Monsanto Environmental Health Laboratory, 1982. ${ }^{\text {f) }}$ Represents maximum attainable atmospheric concentration.

Table 2 Results of acute toxicity tests with Lasso ${ }^{\circledR}$ EC herbicide.

\begin{tabular}{|c|c|c|}
\hline $\begin{array}{l}\text { Route of } \\
\text { administration }\end{array}$ & Species & Median lethal dose \\
\hline \multirow[t]{2}{*}{ Oral } & $\mathrm{Rat}^{\mathrm{a})}$ & $1000 \mathrm{mg} / \mathrm{kg}$ \\
\hline & Mouse $^{\mathrm{b})}$ & $1480 \mathrm{mg} / \mathrm{kg}$ \\
\hline Dermal & Rabbit ${ }^{\text {a) }}$ & $8000 \mathrm{mg} / \mathrm{kg}$ \\
\hline Inhalation & $\mathrm{Rat}^{\mathrm{a})}$ & $>6.5 \mathrm{mg} / l^{\mathrm{d})}$ \\
\hline
\end{tabular}

izer in the guinea pig. (Bio/dynamics Inc., 1983)

\section{SUBCHRONIC TOXICITY STUDIES}

\section{Six-Month Oral Study in Dogs}

Alachlor was initially administered orally via gelatin capsules to groups of 6 male and 6 female beagle dogs at dose levels of $0,25,50$, and $100 \mathrm{mg} / \mathrm{kg} / \mathrm{day}$. The animals were housed individually in suspended stainless steel cages. The high dose level was reduced to $75 \mathrm{mg} /$ $\mathrm{kg} /$ day after 3 weeks because of severe toxicity. Additional groups of 6 males and 6 females were added to the study at dose levels of 0 and $5 \mathrm{mg} / \mathrm{kg} /$ day when it appeared that a lower dose level may be needed to establish a NOEL (no observed effect level). All animals were dosed for approximately 6 months ( 27 weeks). Mortality was observed at and above $25 \mathrm{mg} / \mathrm{kg} /$ day. Kidney weights were increased at 50 and $75 \mathrm{mg} / \mathrm{kg} / \mathrm{day}$, but the toxicological significance of this finding is doubtful in the absence of any correlative histologic lesion. Liver toxicity was noted in dogs given doses of $25 \mathrm{mg}$ / $\mathrm{kg} /$ day and higher as manifested by increased serum enzyme levels and the occurrences of microscopic lesions. Indications of anemia were also noted in dogs given doses of $25 \mathrm{mg} / \mathrm{kg} /$ day and above. An apparent increase in liver weight in male dogs given the $5 \mathrm{mg} / \mathrm{kg} /$ day dose was not considered toxicologically significant because there was no indicator of hepatotoxicity (e.g. increased enzymes or microscopic lesions) and no evidence of liver toxicity in the subsequent 1 year dog study at $10 \mathrm{mg} / \mathrm{kg} /$ day. Thus, the NOEL for subchronic toxicity in dogs is considered to be $5 \mathrm{mg} / \mathrm{kg} /$ day.

(Pharmacopathics Research Laboratories, 1981)

\section{Ninety-Day Feeding Study in Rats}

Alachlor was administered in the diet to groups of 10 male and 10 female Sprague-Dawley rats at concentrations of $0,100,200,400$, and $800 \mathrm{ppm}$. The animals were housed individually in aluminum rat cages. Several hematologic and biochemical changes were observed in treated animals when compared with controls, however, these changes were either not dose related, not consistent across sexes and/or not supported by pathology findings. None of these changes were considered to be related to alachlor administration. No effects were observed in any of the other parameters examined. The NOEL is considered to be $800 \mathrm{ppm}$ (approximately 40 $\mathrm{mg} / \mathrm{kg} /$ day).

(Tokyo Dental University, 1972)

\section{Ninety-Day Feeding Study in Mice}

Alachlor was administered in the diet to groups of 10 male and 10 female ICR-JCL mice at concentrations of 0 , $100,200,400$, and $800 \mathrm{ppm}$. The animals were housed in synthetic resin cages, five mice per cage. Increases in the absolute and relative liver and kidney weights of treated females and decreases in the absolute and relative spleen weights of males from the 100,400 , and $800 \mathrm{ppm}$ groups were observed. However, these changes were not considered to be related to alachlor administration. No effects were observed on mortality, body weights, food consumption, hematology, biochemistry, and gross or microscopic pathology. The NOEL is considered to be $800 \mathrm{ppm}$ (approximately $40 \mathrm{mg} / \mathrm{kg} /$ day).

(Tokyo Dental University, 1972)

\section{Thirteen-Week Feeding Study in Mice}

Alachlor was administered in the diet to groups of 10 male and 10 female CD-1 mice at concentrations of 0 , $1000,1500,2000$, and $25,000 \mathrm{ppm}$ for 13 weeks. The animals were housed individually in stainless steel cages with wire mesh bottoms suspended over paper bedding. The only definitive treatment-related effects were increased relative and/or absolute liver weights at 1500 , 2000 , and $2500 \mathrm{ppm}$. Increased relative kidney weights at 2000 and $2500 \mathrm{ppm}$ were considered to be possibly related to treatment. However, there were no functional or pathological effects in either the liver or kidneys. The NOEL is considered to be $1000 \mathrm{ppm}$ (154 and 235 $\mathrm{mg} / \mathrm{kg} /$ day for males and females, respectively).

(Monsanto Environmental Health Laboratory, 1992)

\section{CHRONIC TOXICITY AND ONCOGENICITY STUDIES}

1. Twelve-Month Oral Study in Dogs

Alachlor was administered orally via gelatin capsules 
to groups of 6 male and 6 female beagle dogs at dose levels of $0,1,3$, and $10 \mathrm{mg} / \mathrm{kg} /$ day for 52 weeks. The animals were housed individually in stainless steel cages. There was no effect on survival in treated dogs. The body weight of high dose males was reduced at the end of the study. Evidence of minor gastrointestinal distress was noted at 10 , and possibly, $3 \mathrm{mg} / \mathrm{kg} /$ day. Anemia occurred in high dose group males, and to a very minor degree, in mid dose $(3 \mathrm{mg} / \mathrm{kg} /$ day $)$ males. Increased liver weights and bromosulphalein (BSP) were observed in high dose animals. Histologic examination revealed hemosiderin deposition in renal tubular epithelium, hepatocytes, and splenic phagocytes of high dose males. Very slight hemosiderin deposits were found in the kidney of one mid dose male and the spleen of another. The hemosiderin deposition correlates well with the hematology findings and is indicative of hemolytic anemia. The chronic NOEL in dogs is considered to be 1 $\mathrm{mg} / \mathrm{kg} /$ day.

(Pharmacopathics Research Laboratories, 1984)

\section{Two-Year Chronic Toxicity/Oncogenicity Studies in Rats}

1) Alachlor was administered to groups of 50 male and 50 female Long-Evans rats in the diet at dose levels equivalent to $0,14,42$, and $126 \mathrm{mg} / \mathrm{kg} / \mathrm{day}$. The animals were housed individually in elevated stainless steel cages. Male and female rats were sacrificed after 116 weeks (27 months) and 106 weeks (24 months), respectively.

At the end of the study, mean body weights were reduced in males at $42 \mathrm{mg} / \mathrm{kg} /$ day and in both sexes (16$20 \%$ ) at $126 \mathrm{mg} / \mathrm{kg} /$ day. The mean survival time of high dose animals was also significantly reduced. Inlife eye examinations revealed the presence of a progressive uveal degeneration syndrome which was characterized by free floating iridial pigment in the ocular chambers and pigment deposition on the cornea and lens; degeneration/cataract formation also occurred in the rats most severely affected. At termination, the syndrome was present in all surviving high-dose rats, approximately $67 \%$ of the mid dose rats, and none of the surviving low dose rats. At the week 88 examination, 2-of-43 low dose rats may have exhibited the mildest form of the syndrome unilaterally, but they died prior to subsequent examinations. However, no additional low dose rats developed ocular abnormalities even though several mid dose rats acquired the syndrome during this period. The uveal degeneration syndrome observed in the Long-Evans rat is considered to be a peculiar response in this strain because the response has not been observed in mice, dogs, or other strains of rats treated with alachlor.

Liver weights were elevated in high dose males and females. Microscopic evidence of hepatocellular toxicity (e.g. central lobular necrosis) was seen primarily in
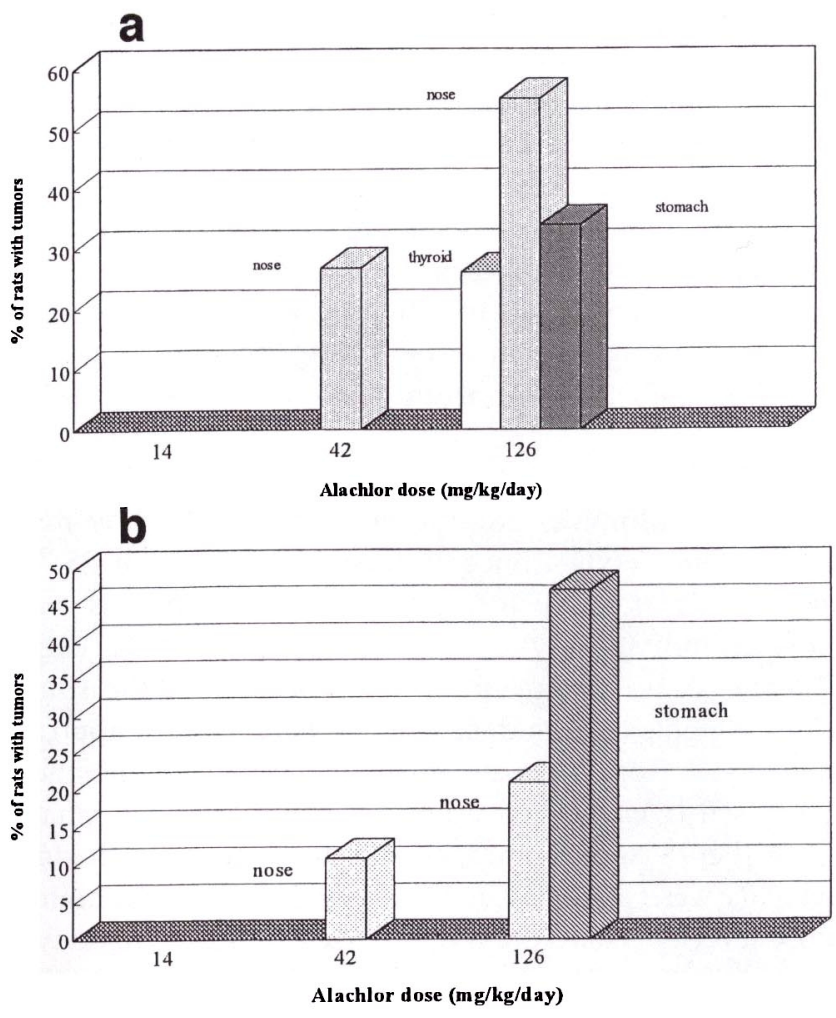

Fig. 1 Incidences of nasal, thyroid, and stomach tumors in Long-Evans rats from the first oncogenicity bioassay. a, males; $b$, females

42 and $126 \mathrm{mg} / \mathrm{kg}$ /day dose group animals but also in some animals at $14 \mathrm{mg} / \mathrm{kg} /$ day. Neoplastic lesions were observed in the nasal turbinate mucosa, glandular stomach mucosa, and thyroid follicular epithelium (Figs. la and $1 \mathrm{~b}$ ). Significant increases in stomach and thyroid (males only) tumor incidences were limited to the highest dose tested, a dose which exceeded the Maximum Tolerated Dose (MTD). Because of non-neoplastic toxicity in the liver, and possibly eyes, of low dose animals, no NOEL was established for chronic effects in this study.

(Bio/dynamics Inc., 1981)

2) A second chronic study was conducted with LongEvans rats to follow up on effects seen in the previous study and to establish a definitive NOEL. Alachlor was administered to groups of 50 male and 50 female rats in the diet at dosages of $0,0.5,2.5$, and $15 \mathrm{mg} / \mathrm{kg} /$ day for approximately 25 months. The animals were housed individually in stainless steel mesh cages suspended over paper bedding. The nasal tumors noted in the previous study were also observed in several animals from the 15 $\mathrm{mg} / \mathrm{kg} / \mathrm{day}$ group and in a single rat dosed at $2.5 \mathrm{mg} /$ $\mathrm{kg} /$ day. No tumors were observed in the stomach or thyroid. There were no indications of hepatotoxicity or ocular lesions in animals treated with alachlor at any dose level. The only non-neoplastic effect was nasal inflammation and submucosa gland hyperplasia in ani- 
mals from the $15 \mathrm{mg} / \mathrm{kg} / \mathrm{day}$ group. These findings are considered to be unrelated to the neoplastic response. Base on the results of additional studies to investigate the mechanisms of tumor formations observed with alachlor in rats, it was concluded that non-genotoxic, threshold -based mechanisms are operative for formation of these tumors in nasal, stomach and thyroid. ${ }^{6-16)}$ The NOEL for all non-neoplastic and neoplastic chronic effects in this study is considered to be $0.5 \mathrm{mg} / \mathrm{kg} /$ day.

(Monsanto Environmental Health Laboratory, 1984)

\section{Eighteen-Month Oncogenicity Studies in Mice}

1) Alachlor was administered to groups of 50 male and 50 female CD-1 mice in the diet at levels of $0,26,78$, and $260 \mathrm{mg} / \mathrm{kg} /$ day for 79 weeks. The animals were housed individually in elevated stainless steel cages. There was no treatment-related mortality in the study. Body weights of high dose females were reduced approximately $7 \%$ from week 50 through the end of the study. Increased liver weights were noted in males and females from the 78 and $260 \mathrm{mg} / \mathrm{kg} /$ day dose groups. Kidney weights were also elevated in males at these two highest dose levels. Therefore, the NOEL for chronic toxicity is considered to be $26 \mathrm{mg} / \mathrm{kg} /$ day. The incidence of benign pulmonary tumors in high dose females was slightly but statistically higher than the control value. Because this incidence was within the historical control range and there was no evidence of preneoplastic effects or other indicators of an oncogenic response (e.g. multiplicity or progression to malignancy), the tumors were considered to be unrelated to alachlor administration.

(Bio/dynamics Inc., 1977)

2) As part of reregistration procedures in Europe, a second mouse bioassay was done using updated testing guidelines. This study was conducted at concentrations of $0,100,400$, and $1600 \mathrm{ppm}$ for 18 months. These concentrations corresponded to approximate dose levels of $0,20,78$, and $331 \mathrm{mg} / \mathrm{kg} /$ day. The animals were housed individually in stainless steel cages with wire mesh bottoms suspended over paper bedding. The 1600 ppm dose level produced: marginally reduced body weight gain; increases in liver weight, serum sodium/ chloride (females); and increased incidences of fibrous osteodystrophy of the bone (females), liver eosinophilic foci (males), and chronic nephritis (males), a common age-related degenerative disease. The incidence of liver hypertrophy was increased in males at the 400 and 1600 ppm dietary levels. The severity of the hypertrophy was generally minimal-to-slight and also slightly increased only at 400 and $1600 \mathrm{ppm}$. This finding is considered to be a metabolic adaptive change rather than a toxic response. The low dose of $100 \mathrm{ppm}(20 \mathrm{mg} / \mathrm{kg} /$ day for combined sexes) is considered to be the NOEL.

(Monsanto Environmental Health Laboratory, 1994) In the second mouse bioassay, the incidences of bron- choalveolar neoplasms appeared to be higher in some groups of treated animals, although the incidences were not dose-related. Given the inconsistent/nonreproducible nature of the results within and between the two mouse bioassays, all slides and data were evaluated by a panel of expert pathologists to assess a possible relationship to treatment. The following additional factors were considered: lung tumors in treated mice were morphologically like age-associated tumors commonly seen spontaneously; there were no differences in preneoplastic changes, tumor multiplicity, progression to malignancy, or tumor latency between control and treated mice. Finally, it was noted that alachlor is non-toxic to the lung (as evidenced by the lack of tissue damage or cell proliferation in either study), and autoradiography data show no localization in the lung; these factors indicate that the lung is not a target tissue. Based on all these observations, the panel concluded that the weight of evidence indicates that alachlor administration does not cause an increase in lung tumors in mice.

$$
\text { (Pathco., Inc., 1995) }
$$

\section{GENOTOXICITY STUDIES}

To support registrations worldwide, the genotoxic potential of alachlor has been evaluated in numerous assay systems using a variety of species, metabolic activation conditions, and endpoints. ${ }^{3)}$ These assays tested alachlor produced by Monsanto in well-validated systems using established testing guidelines according to Good Laboratory Practice standards. Alachlor was tested at levels up to $5000 \mu \mathrm{g}$ per plate in microbial assays with five $S$. typhimurium strains (TA98, TA100, TA1535, TA1537, and TA1538) and one strain of E. coli (WP2 hcr) with and without a rat liver metabolic activation system. The test material did not induce reverse gene mutations under any of the assay conditions. Alachlor was negative when tested up to cytotoxic levels in a Chinese hamster ovary $(\mathrm{CHO})$ mammalian cell gene mutation assay. Alachlor was not clastogenic to rat bone marrow cells in an in vivo cytogenetics assay when administered orally at dose levels up to $1000 \mathrm{mg} / \mathrm{kg}$. Alachlor did not exhibit in vivo mammalian genotoxicity in rat and mouse micronucleus assays conducted at doses of $600 \mathrm{mg} / \mathrm{kg}$ (i.p.) and $1000 \mathrm{mg} / \mathrm{kg}$ (p.o.), respectively. Alachlor was negative in in vivo/in vitro rat UDS assays at dose levels below $1000 \mathrm{mg} / \mathrm{kg}$; variable responses were observed at an oral dose of $1000 \mathrm{mg} / \mathrm{kg}$. This dose is near the oral $\mathrm{LD}_{50}$ and has been shown to produce severe hepatotoxicity. Therefore, the biological relevance of the results at $1000 \mathrm{mg} / \mathrm{kg}$ is doubtful. The potential of alachlor to damage DNA was also evaluated in vitro in a bacterial recombination assay with Bacillus subtilis using $\mathrm{rec}^{+}$and $\mathrm{rec}^{-}$strains. Alachlor was tested up to $2000 \mu \mathrm{g}$ per disc, and no genetic damage was observed. Further studies have focused on nasal tissue, a target site 
for induction of tumors in the rat. Nasal turbinate S9 metabolic activation systems from rats, mice, and monkeys did not activate alachlor, a secondary sulfide metabolite of alachlor, or diethyl aniline to mutagens detectable in the Ames assay.

It is concluded that alachlor does not have significant genotoxic potential in mammals. This conclusion is supported by an analysis of the alachlor genotoxicity data using a scoring system developed by the International Commission for Protection against Environmental Carcinogens and Mutagens. ${ }^{4,5)}$ This system generates an overall score using data from multiple test systems incorporating various weight of evidence considerations (e.g. doses used, species tested, in vitro vs. in vivo). Alachlor's score of -9 clearly positions it well in the non-genotoxic range of the evaluation system and provides objective confirmation of the conclusions from careful expert evaluation that alachlor does not have general genotoxic potential. Furthermore, the alachlor genotoxicity results support the conclusion that the ratspecific oncogenic response does not result from genotoxicity but rather from alachlor's effects on non-genotoxic processes.

\section{EVALUATION OF THE ONCOGENIC POTENTIAL OF ALACHLOR}

As noted above, neoplastic responses attributable to alachlor administration were observed in the stomach, thyroid, and nasal tissue of rats. Significant increases in stomach and thyroid tumors were restricted to the highest dose tested (i.e. $126 \mathrm{mg} / \mathrm{kg} / \mathrm{day}$ ). This high dose is considered to have exceeded a maximum tolerated dose (MTD) as evidenced by excessive body weight loss, hepatocellular necrosis, and decreased survival. The production of tumors only under these extreme conditions of exposure in rats is of doubtful relevance for humans. Although nasal tumors were produced at lower dose levels, a weight-of-evidence evaluation of data obtained from extensive mutagenicity testing reveals that alachlor has no significant genotoxic activity in mammalian systems. These data strongly suggest that tumors observed in the rat are arising through non-genotoxic, threshold-sensitive mechanisms. To better understand the mechanisms involved in the production of these rodent tumors and their relevance to humans, a series of additional investigations were undertaken. These additional studies have been communicated in detail elsewhere, and the results are summarized below.

\section{Rat Nasal Tumors}

Extensive investigations have demonstrated significant species differences in the metabolism and pharmacokinetics of alachlor and have provided a mechanistic basis for the rat-specific production of nasal tumors as follows. Alachlor and its metabolites are converted to a diethyl quinoneimine metabolite, DEIQ, in rat nasal tissue. ${ }^{6)}$ This metabolite forms protein adducts, ${ }^{7}$ which leads to cytotoxicity, prolonged cell proliferation and the eventual development of the predominantly benign, microscopic nasal tumors observed. This cell proliferation is considered to be a prerequisite for nasal tumor development, and its induction is threshold-sensitive, i.e., there is a dose below which cell proliferation and the ensuing tumor formation do not occur.

Critical differences in enterohepatic circulation and target tissue metabolism result in greater formation of DEIQ in rat nasal mucosa as compared to other species. Rat nasal tissue contains high levels of enzymes which metabolize alachlor to 4-amino-3,5-diethylphenol (DEAphenol), the precursor to DEIQ. For example, the ability of rat nasal tissue to convert the secondary sulfide metabolite of alachlor to 2,6-DEA-phenol, the proximate metabolite of DEIQ, is more than 30 times greater than that of monkeys ${ }^{8)}$ and 751 times greater than that of human nasal tissue. ${ }^{9)} \quad$ Species differences are even larger when the relative enzymatic rate of the initial metabolic step (alachlor conjugation to glutathione) is included in the overall rate of DEA-phenol formation from alachlor. When this is done, the overall ability of rats to convert alachlor to DEA-phenol is 3000- and 22,000-fold higher than that of humans when the initial glutathione conjugation occurs in the liver or nose, respectively. ${ }^{9)}$ These data indicate that the potential for the formation of the reactive DEIQ metabolite in human nasal tissue is negligible. The results further support the view that the rat is not an appropriate model for an assessment of alachlor's oncogenic risk to humans.

\section{Rat Stomach Tumors}

The majority of the work conducted to elucidate the mechanism by which chloroacetanilide herbicides induce stomach tumors in rats was conducted with butachlor, a close structural analog of alachlor which produces the same neoplastic response. A stomach tumor initiationpromotion study was conducted with butachlor as part of this research program. ${ }^{10)}$ Butachlor had no activity as an initiator, but did promote tumor formation following treatment with a known initiator. Thus, the results from this study have produced direct experimental evidence indicating a non-genotoxic mode of action for stomach tumorigenicity. A subsequent tumor promotion study showed that alachlor produced stomach tumors via the same promotional activity.

Mechanistic studies with butachlor have shown that high dose exposure leads to mucosal atrophy with an accompanying profound loss of parietal cells as the initial lesion. ${ }^{11,12)}$ The resulting gastric hypochlorhydria and increased $\mathrm{pH}$ induces a compensatory production of gastrin. Together, the progressive mucosal atrophy and excessive gastrin secretion drive a proliferative response 
which culminates with tumor formation. It was subsequently demonstrated that long-term high dose alachlor exposure also produced mucosal atrophy, hypochlorhydria, and marked hypergastrinemia, all hallmarks of the unique oncogenic mechanism delineated for butachlor. Alachlor did not produce mucosal atrophy at a lower, non-oncogenic dose level. The results of these mechanistic investigations, in conjunction with the demonstrated promotional activity, provide strong evidence that alachlor produces stomach tumors in rats through the same non-genotoxic mechanism as butachlor.

This indirect mechanism of chloroacetanilide-induced stomach tumors does not present a human risk, since the conditions driving the requisite threshold-sensitive events are operative only in rats chronically exposed to very high dose levels. The prolonged exposure to excessively toxic doses required for tumorigenesis in rats could not occur in humans. Even if such exposure did occur, a study with rhesus monkeys showed that the key preneoplastic event (mucosal atrophy) does not occur in primates even at a dose that is twice that required to produce stomach tumors in rodents. Thus, there is compelling data supporting the conclusion that the stomach tumors are of no relevance to humans.

\section{Rat Thyroid Tumors}

Results from mechanistic work have shown that high dose alachlor exposure results in increased thyroid hormone elimination via induction of hepatic UDPGT activity, thereby causing a long-term, compensatory increase in circulating TSH levels. ${ }^{13)}$ It is widely recognized that such prolonged stimulation of the thyroid gland via elevated TSH secretion leads to follicular cell hyperplasia and neoplasia in experimental animals. ${ }^{14-16)}$ This hormone-mediated mechanism of carcinogenesis is considered to be a threshold phenomenon to which rats are particularly susceptible. The results with alachlor provide strong evidence that this non-genotoxic mechanism is operative in the production of alachlor-induced thyroid tumors in rats.

\section{REPRODUCTION AND DEVELOPMENTAL TOXICITY STUDIES}

\section{Three-Generation Reproduction Study in Rats}

Groups of 10-12 male and 17-24 female SpragueDawley rats were fed alachlor in the diet at dose levels of $0,3,10$, and $30 \mathrm{mg} / \mathrm{kg} /$ day. Dosing was continuous throughout premating, mating, pregnancy, and lactation periods for 3 successive generations. Each parental generation was mated to produce two litters per generation. Offspring from the second litters were selected to be parents for the subsequent generation. All animals were given a gross necropsy. Mating and fertility indices, as well as offspring weight/survival at birth and throughout lactation was evaluated for all litters. His- topathological evaluation was conducted on 10 male and 10 female control and high dose parents from all three generations as well as pups from the second litter of the last generation $\left(\mathrm{F}_{3} \mathrm{~b}\right)$. No adverse effects were observed on any reproductive parameter in any generation. Therefore, the NOEL for reproductive toxicity in rats is considered to be $30 \mathrm{mg} / \mathrm{kg} /$ day.

(Bio/dynamics Inc., 1981)

\section{Developmental Toxicity Study in Rats}

Alachlor was administered in corn oil by gavage to four groups of mated Sprague-Dawley female rats at dosages of $0,50,150$, and $400 \mathrm{mg} / \mathrm{kg} /$ day on days 6 through 19 of gestation. Fetuses were obtained on gestation day 20, examined externally, weighed, and processed for skeletal and soft tissue examinations. Maternal and fetal toxicity occurred in the high dose group as evidenced by maternal deaths, a slight decrease in fetal body weight, and a slight increase in postimplantation loss. No malformations were observed in treated offspring. The NOEL for both maternal and developmental toxicity in the rat is considered to $150 \mathrm{mg} /$ $\mathrm{kg} /$ day.

(International Research and Development Corp., 1980)

\section{Developmental Toxicity Study in Rabbits}

Three groups of 18 mated female Dutch belted rabbits were administered alachlor by oral gavage in corn oil at dosages of 50,100 , and $150 \mathrm{mg} / \mathrm{kg} /$ day. An additional 20 mated females received only corn oil and served as controls. All animals were dosed daily from gestation day 7 through 19. All surviving females were sacrificed on gestation day 30 and routine uterine examinations were performed. All fetuses were weighed and examined for external malformations. Each fetus was then examined internally by dissection and then stained for skeletal evaluation.

The administration of alachlor resulted in maternal toxicity as indicated by maternal body weight loss at 150 $\mathrm{mg} / \mathrm{kg} /$ day and decreased food consumption at levels of 100 and $150 \mathrm{mg} / \mathrm{kg} / \mathrm{day}$. There were no indications of embryotoxicity, fetal toxicity or malformations in any treated group. Therefore, the NOELs for maternal and developmental toxicity in the rabbit are considered to be 50 and $150 \mathrm{mg} / \mathrm{kg} /$ day, respectively.

(Bio/dynamics Inc., 1988)

\section{PHARMACOLOGY STUDIES}

Alachlor was administered intraperitoneally to groups of 3 male and 3 female ICR mice at single doses of 0 , $19.5,78.1,313,1250$, and $5000 \mathrm{mg} / \mathrm{kg}$. All animals given the two highest dose levels died during the study. Male and female mice given alachlor at doses of $313 \mathrm{mg} /$ $\mathrm{kg}$ and above exhibited abnormal signs of toxicity characterized by excitation of the central nervous system and 
non-specific depression of activity. No signs of toxicity were observed in animals given alachlor at dose levels of 19.5 or $78.1 \mathrm{mg} / \mathrm{kg}$. Hexobarbital sleeping time was prolonged in mice given doses of 78.1 and $313 \mathrm{mg} / \mathrm{kg}$. The transport activity of the small intestine was inhibited at $313 \mathrm{mg} / \mathrm{kg}$.

Acute oral administration of alachlor to 3 male albino rabbits at dose levels of $0,78.1,313,1250$, and $5000 \mathrm{mg} /$ $\mathrm{kg}$ resulted in deaths of the animals at the two highest dose levels tested. Prior to death, animals receiving these lethal doses also exhibited abnormal signs indicating non-specific depression in several aspects of behavioral, somatic, and autonomic functions. No abnormal clinical signs were noted in animals given doses of 78.1 or $313 \mathrm{mg} / \mathrm{kg}$. There were no distinct changes in EEG, respiratory rate, blood pressure, electrocardiogram, or heart rate at or below $313 \mathrm{mg} / \mathrm{kg}$. A decrease in body temperature was noted only in animals given the 1250 $\mathrm{mg} / \mathrm{kg}$ dose. Plasma hemoglobin and prothrombin times were increased in the $1250 \mathrm{mg} / \mathrm{kg}$ group. Activated partial thromboplastin time was not affected.

In conclusion, alachlor produced various clinical and pharmacological effects, primarily at acutely lethal dose levels. Effects generally disappeared within a few hours. The high dose levels required to produce severe effects confirm that the acute toxicity of alachlor is relatively low.

(The Institute of Environmental Toxicology, 1993)

\section{EPIDEMIOLOGY STUDIES}

Three epidemiology studies have been conducted on alachlor manufacturing workers which focus on the ocular and oncogenic effects seen in the rat bioassays. A group of the highest-exposed workers was examined for the presence of a specific eye abnormality, analogous to the initiating lesion in Long-Evans rats, called pigmentary dispersion syndrome (PDS). ${ }^{17)}$ None of the exposed workers had PDS, and prevalence rates for other eye abnormalities were similar in exposed and unexposed individuals. In another study, there was no indication of increased mortality rates from cancer or any other causes among workers with up to 25 years of followup. ${ }^{18)}$ Likewise, cancer incidence rates over a 24-year period were not elevated in the highest-exposed alachlor workers, nor were there any cases of tumors in the nose, stomach, or thyroid, the organs in which oncogenic effects were produced in rats. ${ }^{18)}$ These manufacturing workers had year-round exposure greatly exceeding agricultural exposure, which is limited to a two- or three week period prior to planting in the spring. In fact, manufacturing exposure was estimated to exceed yearly agricultural exposure by a factor of 10,000 or more. ${ }^{19}$ Potential dietary exposures are even lower than agricultural exposure. Therefore, the absence of eye effects and increased mortality and cancer rates in manufacturing workers serve as an important indicator of the low potential for adverse effects among the general population, who are exposed to extremely low levels of alachlor if at all.

\section{CONCLUSIONS}

The results of tests in laboratory animals indicate that alachlor has low mammalian toxicity following acute oral, dermal, and inhalation exposure. Alachlor has some potential to produce allergic skin reactions following repeated or prolonged exposure. Subchronic and chronic exposure produces primarily liver and kidney toxicity for which large margins of safety exist. Ocular effects were produced in Long-Evans rats but have not been observed in Sprague-Dawley rats, CD-1 mice, beagle dogs or humans. Alachlor does not have general genotoxic potential and does not interfere with normal reproductive and developmental processes. Alachlor is not oncogenic in the CD-1 mouse. Neoplastic lesions in the rat are observed in the nasal turbinate mucosa, stomach glandular mucosa, and thyroid follicular epithelium. Significant increases in the stomach and thyroid tumors occurred only at the highest dose tested which produced excessive toxicity.

A large body of data supports the conclusion that alachlor produces these tumors in rats through nongenotoxic mechanisms for which thresholds exist. The tumors are not accompanied by DNA damage as assessed in target tissue itself and in other standard in vivo mammalian assays up to the MTD. The conditions driving the requisite threshold-sensitive preneoplastic events occur only in experimental studies employing doses at and above the Maximum Tolerated Dose (MTD). Observed species differences in physiology and metabolism indicate that the rat is particularly susceptible to the induction of nasal, thyroid and stomach tumors following chronic exposure to this agent. Consequently, humans would be at significantly lower risk for development of these tumors. In fact, substantial margins of safety do exist, as human exposure is several orders of magnitude below the doses producing tumors in rats. Therefore, it is concluded that the alachlorinduced tumors in rats are not relevant to humans under actual conditions of exposure. This conclusion is supported by the lack of mortality and tumors in manufacturing workers who have the highest exposure to alachlor.

In summary, an extensive health and safety database has been developed to support the registration of alachlor and LASSO ${ }^{\circledR}$ products worldwide. A thorough evaluation of these data indicates that alachlor products are of generally low toxicity and present minimal opportunity for human exposure. When used in accordance with label directions, alachlor will not adversely affect human health. 
Based on the review of the studies summarized above, the Japan Ministry of Health and Welfare (MHW) established an Acceptable Daily Intake (ADI) for alachlor as $0.005 \mathrm{mg} / \mathrm{kg} /$ day with the NOEL from the chronic rat study of $0.5 \mathrm{mg} / \mathrm{kg} /$ day and the safety factor of 100 . This ADI supports the current withholding limits established by the Japan Environmental Agency (EA) of 0.05 $\mathrm{ppm}$ in grains (excluding rice), and beans, and $0.01 \mathrm{ppm}$ in vegetables, potatoes, sugar beet, sugarcane and fruits.

\section{REFERENCES}

1) Buehler: Arch. Dermatol. 91, 171 (1965)

2) H. Ritz \& E. Buehler: "Current Concepts in Cutaneous Toxicity," ed. by V. Drill \& P. Lazar, Academic Press, New York, pp. 25-40, 1980

3) L. Kier, W. Heydens, H. Lau, D. Thake, K. Asbury \& A. Wilson: Toxicologist 30, Part 2, Abstract 1182 (1996)

4) D. Brusick, J. Ashby, F. de Serres, P. Lohman, T. Matsushima, B. Matter, M. Mendelsohn, D. Moore II, S. Nesnow \& M. Waters: Mutat. Res. 266, 1 (1992)

5) P. Lohman, M. Mendelsohn, D. Moore II, M. Waters, D. Brusick, J. Ashby \& W. Lohman: Muta. Res. 266, 7 (1992)

6) P. Feng, A. Wilson, R. McClanahan, J. Patanella \& S. Wratten: Drug Metab. Dispos. 18, 373 (1990)

7) A. Wilson, H. Lau, K. Asbury, D. Thake \& W. Heydens: Presented at International Congress of Toxicology-VII, Seattle, 1995

8) A. Li, K. Asbury, W. Hopkins, P. Feng \& A. Wilson: Drug Metab. Dispos. 20, 616 (1992)

9) A. Wilson, H. Lau, K. Asbury \& W. Heydens: Toxicologist 15, Abstract 1398 (1995)

10) A. Wilson, D. Branch, M. Shibata, D. Thake, T. Shirai \& A. Hagiwara: Presented at Annual Conference of International Federation of Societies of Toxicologic Pathologists, Tours, 1995

11) G. Hard, M. Iatropoulos, D. Thake, D. Wheeler, M. Tatematsu, A. Hagiwara, G. Williams \& A. Wilson: Exp. Toxic. Pathol. 47, 95 (1995)

12) D. Thake, M. Iatropoulos, G. Hard, K. Hotz, C. Wang, G. Williams \& A. Wilson: Exp. Toxic. Pathol. 47, 107 (1995)

13) A. Wilson, D. Thake, W. Heydens, D. Brewster \& K. Hotz: Fundam. Appl. Toxicol. 33, 16 (1996)

14) R. Hill, L. Erdreich, O. Paynter, P. Roberts, S. Rosentahl \& C. Wilkinson: Fund. Appl. Toxicol. 12, 629 (1989)

15) G. Thomas \& E. Williams: Mutat. Res. 248, 357 (1991)

16) G. Zbinden: Arch. Toxicol. Suppl 12, 98 (1988)

17) B. Ireland, J. Acquavella, T. Farrell, M. Anne \& T. Fuhremann: J. Occup. Med. 36, 738 (1994)

18) J. Acquavella, S. Riordan, M. Anne, J. Collins, B. Ireland \& W. Heydens: Environ. Health Perspect. 104 (7), 2 (1996)

19) J. Acquavella, B. Ireland, T. Leet, M. Anne, T. Farrell \& M. Martens: In: Proceedings of the XII Joint CIGR, IAAMRH, IUFRO International Symposium: Health, Safety and Ergonomic Aspects in Use of Chemicals in Agriculture and Forestry, June, 1993, Kiev, Ukraine: Institute for Occupational Health 184, 1994

\section{要 約 \\ アラクロール毒性試験の概要 \\ 米国モンサント・カンパニー毒性部}

アラクロールは，米国モンサント・カンパニーが開発し た一年生イネ科雑草および一部の広葉雑草を対象とする畑 作用除草剂である. 動物実験の結果, 本剂の哺乳動物に対 する急性経口, 経皮, 吸入毒性はいずれも軽微で, 眼およ び皮膚一次刺激性は低い.モルモットを用いた皮膚感作性 試験において陽性の反応が認められた。亜急性および慢性 毒性試験の結果, 主として肝臓および腎臓に検体投与によ る影響が認められたが,これらの影響には閾值が存在した。 ラットを用いた慢性毒性／発がん性併合試験において腺 胃，鼻部および甲状腺の腫瘍が認められたが，腫瘍発生の メカニズムに関する試験研究の結果, これらの腫瘍は閾值 の存在する非遺伝子傷害性の作用によって引き起こされて いることが解明されている。これらの腫瘍の発生に結びつ く前段階の症状には闇值があり, 最大耐量以上の用量でア ラクロールを投与した動物実験においてのみ認められた。 また，鼻部の腫瘍の発生には，ラットにおいてのみ認めら れる種特異的代謝が関与していた。このようにラットにお いて観察された腫瘍をヒトに外挿することは妥当ではな い.この結論は，アラクロールへの暴露量が最も高いと考 えられるアラクロール製造工場の労働者を対象とした疫学 調査の結果, 死亡率および腫瘍発症率の増加が認められな かったことからも支持されている。本剤には，哺乳動物生 体内における遺伝毒性は認められず，正常な繁殖や発生過 程を阻害することもなかった。

ここに要約した毒性試験成績の評価に基づき，ラットに おける慢性毒性/発がん性併合試験における無毒性量 0.5 $\mathrm{mg} / \mathrm{kg} /$ 日および安全係数 100 を用い, $0.005 \mathrm{mg} / \mathrm{kg} /$ 日の ADI が設定されている.

アラクロールは,ラッソー乳剂として昭和 45 年 3 月登録 を取得して以来, 大豆, とうもろこし, 落花生, 野菜, 果 樹等において雑草発生前土壌処理剂として広く使用されて いる，登録保留基準は，麦·雑穀（小麦を除く），大豆，大 豆以外の豆類に $0.05 \mathrm{ppm}$, いも類, 第二大粒果実類, 小粒 果実類, 第一葉菜類, 第二葉菜類, 根 - 茎類, てんさい, さとうきびに $0.01 \mathrm{ppm}$ と設定されている.

\section{Contacts}

Toxicology Division, Monsanto Company, 800 N. Lindbergh Blvd., St. Louis, MO 63167, U.S.A.

Regulatory Affairs Team, Agro-Science Division, Monsanto Japan Limited, Nihonbashi Daini Bldg., 41-12 Nihonbashi Hakozakicho, Chuo-ku, Tokyo 103-0015, Japan 問合せ

日本モンサント株式会社アグロサイエンス事業部規制・環 境部

干103-0015 東京都中央区日本橋箱崎町 41-12 日本橋第 二ビル 